УДК 821.163.41-2.09(437.3)"1918/1989"

821.163.41-2.09(437.6)"1918/1989"

https://doi.org/10.18485/msc50.2019.1.ch66

Иван Доровски

\title{
РЕЦЕПЦИЈА СРПСКЕ ДРАМЕ У ЧЕШКОЈ И СЛОВАЧКОЈ
}

$(1918-1941)$

Тачно пре седамдесет и једну годину изишла је Српскохрватска драмa (1924) Franka Wollmana, која заједно с његовим списом о словеначкој (1925) и бугарској (1928) драми чини аналитичку основу за синтетску студију о словенском Југу. Но, ниједан од тих текстова не нуди целовито тумачење историје позоришта јужних Словена, него им је придодан само „кратак, али достатан преглед развоја југословенског позоришта”. F. Wollman je по моме назору сасвим исправно мислио да су историја позоришта „и драматика, и она тзв. изворна, народна, у врло уској вези, особито код јужних Словена".' (Драматика, предговор, с.в.).

Међутим, Wollmanove појединачне монографије и његова типолошка упоредна синтеза не захватају у потпуности две деценије између два светска рата. Прва међу њима чак даје „преглед историје до рата”, а преостале две само делимично прате послератну историју. Ипак, реч је о виталној традицији, коју је могуће следити у више смерова.

У свом сам раду дао делимично место продору и рецепцији бугарског, хрватског, словеначког и српског драмског стваралаштва на позорницама чешких и словачких позоришта. ${ }^{2}$ Од почетка развоја драме и позоришта јужних Словена па све до 1918. године на нашим су се сценама само врло спорадично и случајно појављивала дела српских, словеначких, хрватских и бугарских аутора. На темељу информација које сам успео прикупити могу устврдити да су се у раздобљу 1880-1918. код нас све у свему изводила 23 позоришна дела југословенских аутора и то у Прагу (13), Брну (5), Плзењу (3) и Кладну (2). Најизвођенији аутори били су Хрват Иво Војновић, Србин Бранислав Нушић те Словенац Иван Цанкар.

У раздобљу од 1918. до 1941. године на чешким су и словачким позорницама извођена драмска дела укупно двадесет тројице југословенских

1 Fr. Wollman, Dramatika slovenského jibu, Праг, 1930, предговор, с. в.

2 I. Dorovský, Dramatické umèni jižnícb Slovanû. Část I. (1918-1938), Брно, 1995. 
аутора. Притом се код тих дела није разликовала национална припадност. Пре је била реч о уметничким вредностима и личним контактима него о пропорционалној заступљености драматике појединачних југословенских националних књижевности међуратног периода. Уосталом, сви су већином били прихватани (како их је схватао и F. Volman) као „Србохрвати” како до 1918. године тако и у доба Краљевине СХC те касније (од 1929. године) Југославије. Б. Нушић или М. Крлежа на пример нису код нас били схватани као српски односно хрватски писци, него понајпре као југословенски аутори. Један и други (као и многи други ствараоци) били су врло значајни како за хрватску тако и за српску културу. Сваки од њих несумњиво је притом поседовао изразиту националну свест. Но, били су свестрано образовани и максимално толерантни те нису били оптерећени национализмом.

Према Дионизу Ђуришину превод садржи елементе међулитерарне рецепције и умјетничке креације. Сасвим природно то је између осталог у вези и с питањем перцепције и аперцепције уметничке вредности оригинала. Функција превода је многозначна. Преводилац најчешће преноси књижевно дело и у њему различит језички систем па га наново гради од новог материјала. Истодобно мора узети у обзир бројне изванкњижевне одреднице нове, друге националне средине, у којој то књижевно дело жели представити. На егзистенцијалну, спознајну и естетску функцију може утицати како књижевнокултурни тако и мимолитерарни развој у некој другој националној средини.

Приликом превода и рецепције уметничког дела из веома блиског или блиског језика примарну функцију нема његова информативна вредност, него његова естетска функција у другој националној средини. Тако је то на пример код превођења и рецепције уметничких дела из појединачних словенских књижевности.

Након првог светског рата и настанка Чехословачке и Краљевине СХС поново је актуализована словенска идеја између осталог у облику узајамног упознавања културних вредности, историје и језика. Дакако, неретко се то догађало више на иницијативу појединаца и разних удружења него државних органа и институција. Стога је словенска идеја углавном имала кампањски карактер. Но ипак су, особито захваљујући Чехословачко-југословенској лиги и њезином обратном партнеру у међународној југословенској држави, многа уметничка дела доспела до чешког и словачког читаоца и слушаоца.

Продор југословенског драмског стваралаштва на чешке и словачке позорнице био је судећи према броју преведених и изведених драма у 
међуратном раздобљу најплоднији у читавој историји чешко-словачкојугословенских културних веза.

Већ постојеће и новостворене позоришне дружине професионалног, полупрофесионалног и аматерског карактера у међуратној Чехословачкој нису се у избору свога репертоара оријентисале само на светско драмско стваралаштво, него и на класична и савремена дела руских, пољских, бугарских, српских, хрватских и словеначких аутора. Притом су нека позоришта задржала своју словенску оријентацију, коју су у музици и драми неговала још пре Првога светског рата. Незанемариву улогу у промицању, прихватању и стваралачкој реализацији музичких и драмских дела одиграли су многи глумци, певачи, режисери, композитори, диригенти и преводиоци, а једнако тако уметничке турнеје, чији допринос у развоју чешко-словачко-југословенских културних веза у међуратном раздобљу ни до данас нажалост није у довољној мери истражен ни вреднован.

Међу најизвођенијим ауторима били су српски комедиограф Бранислав Нушић и хрватски драматичар Иво Војновић. Нека њихова дела била су код нас преведена и извођена и пре 1918. године. Стога не зачуђује чињеница да су њихове нове драме, које су доживеле успех на београдским, загребачким и неким другим сценама, врло брзо продирале на чешке и словачке позорнице.

У нашим лексикографским приручницима недостају информације о рецепцији драмског дела српскога писца хрватског порекла Петра С. Петровића. ${ }^{3}$ Једна од двеју Петровићевих драма, које су настале у првој половини 30. година, врло брзо је нашла пут до нашег позоришта.

Захваљујући афирмисаноме преводиоцу Јарославу Урбану Петровићева драма Ослобађаюе Косте Шљуке изведена је први пут 15. децембра 1938. године у Narodnim divadlu у Прагу под називом Пут праведног. Лаковерни припрости сељак Коста Шљука у тумачењу Јарослава Војте узалудно тражи правду у вези са својим имањем. На крају пружи отпор своме непријатељу. Његов поступак чини се природнији него што је то поступак Густава Тонковића из Необичног човека Гене Сенечића. Према психологији ликова, амбијенту и смислу за драмски ефект, којим је осликао послератно деморализирано славонско село, Петровићев је Пут праведног близак нашој натуралистичкој сеоској драми. То уосталом није промакло ни нашој критици. ${ }^{4}$ Уметнички успех Пута праведног, како је

${ }^{3}$ Slovník světových dramatikũ. Jugoslávští autoři, Prag, 1984. c. 143, Slovník spisovatela Jugoslávie, Prag, 1979, c. 403.

${ }^{4}$ Lumir 1938/1939, децембар 1938. 
гласио наслов у часопису Narodni divadlo, говорио је о позитивном одјеку код нас и у југословенској штампи. „Након успешне премијере пресретан захваљујем свим руководећим делатницима Народног дивадла и свима онима који су заслужни за успех", писао је сам аутор.

Режисер Oldřich Stibor очито је био потакнут прашким успехом Петровићевог Косте Шљуке. Наиме, Пут праведног имао је 15. априла 1939, дакле непуних шест месеци након прашке премијере, премијеру и у Оломоуцу. Критика је исправно оценила режисерову заслугу за успех инсценације ${ }^{5}$, истакнула је добру изведбу читавог глумачког ансамбла те сценографију Ј. Габриела' ${ }^{6}$. Јарослав Раушер у улози Косте Шљуке и уопште Петровићева драма били су „с разумевањем прихваћени од публике”.

Опсежно драмско дело дводомног хрватско-српског драматичара, позоришног теоретичара и режисера Јосипа Кулунџића, који је био један од активних креатора културног живота међуратне Југославије, к нама је нажалост доспело тек у виду његове дебитантске гротеске Поноћ из 1924. године. Режисер Ј. Бородач поставио ју је 11. маја 1928. године у Slovenskom narodnim divadlu у Братислави. Једног од двају дечака тумачио је сам Бородач, а улогу другога поверио је А. Багару.

Позоришни билтен прогласио је Кулунџићеву драму за „смелу комбинацију драмског експресионизма и симболизма, прожету искреним, непатвореним патосом”. Према критици у „Словачком дневнику” аутор није успео креирати драмско дело, које би могло придобити гледаоца. Иако је критика високог вредновала Бородачову режију, сматрала је да је у њу „сувише уложено, а узалуд”.

И из драмског стваралаштва дводомног српско-хрватског аутора Ђуре Димовића, које је до краја 40. година чинило двадесетак драма, до нас је доспела његова једна једина драма. Истину говорећи ни у домовини његове драме нису потакнуле занимање драматурга и режисера. Иако је дебитирао 1913. године, тек је његова драма Свети Игнаци из 1928. године могла доживети светла позорнице.

Захваљујући преводиоцу Ј. Худецу 30. децембра 1930. године доспела је на сцену Народног дивадла његова драма Краљевић Марко из 1919. године. Та је драма, као и већина осталих његових драма, заснована на мотивима богатог народног стваралаштва. Кратевић Марко заправо је други део лабаве трилогије, која почиње трагедијом Војвода Момчило

\footnotetext{
5 Národní divadlo 16, 1938/1939.

6 На истом месту.

7 Našinec, Olomouc, 19. априла 1939, Selské listy, 22. априла 1939.
} 
(1918, премијера у Загребу 1921.) а завршава драмом Ђурађ Смедереваи. Режисер прашке инсценације био је Звонимир Рогоз.

У српској, бугарској и македонској народној епици о јунаку Марку Краљевићу и његовом коњу Шарцу постоје стотине циклуса и пучких песама. Димовићева драма према Wollmanu пати „понајприје од некохерентности радње, која је проузроковала и некохерентност главнога лика, који је неоспорно храбро конципиран".

Д. Димовић није досегнуо изразити уметнички успех стога што није савладао драмску структуру ни језично разврставање ликова. Ипак, његово стваралаштво, које је до становите мере надовезивање на драмску баладу Иве Војновића, значи одређену фазу у развоју српске и хрватске драмске књижевности. „Вековна историја развоја лика Марка на сцени јасно означује не само фазе, кроз које је прошла српскохрватска драматика, него понајпре политичку и ослободитељску тежњу Србохрвата. Прво само сан о великој будућности, онда Марков победнички мач с очима у српским рукама те уједињујућа илирска културна тенденција као изазов Хрвата, потом непосредно пре ослободилачког боја Марко као израз нове силе југословенства и након тога Марко као јунак у непрестаном боју општељудске чежње за највишим. Развој драмског лика није довршен. Марко је понајпре јунак Бугара, али и Албанаца и других Балканаца, тако да је познат у Тракији све до Константинопола. Није ли то заправо прототип човека с Балкана?"9

Аутор наведеног цитата F. Wollman се поводом изведбе Димовићева Кратевића Марка у Прагу чудио што стваралаштво тога већ искусног јужнословенског аутора код нас још није познато. Према Волману: „Историчар књижевности Димовића тешко може некамо сврстати. Он је богоискател, душоборац. Данас се углавном сматра представником драмске баладе."10

Чини се да су чешки и словачки драматурзи изабирали драме југословенских аутора најчешће пригодно и најчешће су оне биле извођене уочи југословенских државних празника.

У рецепцији југословенскога драмског стваралаштва јединствена је појава превода и изведба драме Новина Стевана Клуића. О том аутору не могу се наћи подаци ни у каквом енциклопедијском речнику. Све информације црпимо из „Ческе освете”. У њој је била најављена премијера, а читаоци су укратко били упознати са садржајем драме, чији је аутор био

\footnotetext{
8 Fr. Wollman, Нав. дело, с. 194.

9 На истом месту, с. 195.

10 Národní divadlo 8, 1930/1931.
} 
службеник југословенске амбасаде у Прагу. Драма се бави мотивом односа сељака према земљи и истиче његову важност за послератни мир у земљи. И за аутора информативног чланка ти су мотиви били поприлично наивни, а уз то и на компликован начин обрађени. Ипак је прогнозирао (више да умири аутора дипломату, него због неке изразите уметничке вредности дела) благонаклоност публике према том „вредном примеру југословенског драмског стваралаштва”. назвао На новој груди. На чешки језик ју је превео Б. Шистек променивши наслов у Новина. Свечана премијера у част југословенског посланства одиграла се 16. фебруара 1927. године у Pozorištu na Vinohradech. Режирао jy je Zd. Štěpánek. У првој половици вечери био је изведен трећи део Војновићеве Смрти мајке Југовића под називом Косово.

Име Владимира Велмар-Јанковића данас се не може наћи у речнику драматичара ни писаца, ни у енциклопедији. ${ }^{12}$ Стога будући да је 30 . новембра 1934. остравско позориште извело његов драмски првенац $A \kappa u и-$ онарско друштво Срећа, највероватније се радило о личним контактима или идејној блискости аутора с режисером и ликовним уметником К. Константином. Наиме, у Хрватском народном казалишту та је драма доживела премијеру тек годину дана касније. У оригиналу њезин је назив гласио Срећа а.д. и аутор ју је послао равнатељству загребачког позоришта. Наводно је признао ауторство тек након топлог пријема публике.

У репертоарским плановима чешких и словачких позоришта за сезону 1941/1942. и за сезону 1944/1945, који нису могли бити остварени или су например у Словачкој (у словачком Штату) реализовани уз значајне измене, била је заступљена и југословенска драматика. Нпр. у плану брњенског позоришта био је Држићев Дундо Мароје и Хасанагиница Милана Огризовића те балет Крешимира Барановића Носачек. Братиславски Narodni divadlo требало је извести драматизацију прозе хрватског писца Мила Будака, министра школства и културе хрватске фашистичке владе, под називом Огъиште. Превод Будакових приповедака и романа, које је драматизовао Војмил Рабадан (псеудоним?) које је издала Матица словенска 1944. године, начинио је Вило Ковар. ${ }^{13}$

Служи на част словачким позоришним људима то што до изведбе драматизације Будакових текстова никад није дошло. И то никако због њихове евентуално незнатне уметничке вредности, него због ауторове

11 Česká osvěta 23, 1926/1927, 6p. 7, c. 396.

12 Видети програм драме Словенског Народног Гледалишча по поводу премијере драме Славка Грума Dogodek v mestu Gogi у сезони 1986/1987, с. 60.

13 Slovenská politika, 12. мaja 1944. 
активности у Павелићевој влади. Из кореспонденције дознајемо да је словачки министар унутрашњих послова у Тисовој влади захтевао њезину изведбу на сцени Словенског народног дивадла. Но, његов интендант дp Brezinsky ce бранио. Оградио се одлуком редатељског савјета, који је драму одбио, зато што је њезина изведба изискивала високе трошкове, а и репертоар за сезону 1943/44. већ је био закључен. Следећи аргумент словачких позоришних делатника био је да се на словачким позорницама изводило више драма хрватских (и југословенских) аутора, него словачких драма у хрватским позориштима. ${ }^{14}$

Након ослобођења 1945. године позоришни је живот ушао у ново раздобље у сасвим другачијим друштвеним условима. Стваралаштво не само српских, него јужнословенских аутора у послератним се годинама на чешким и словачким сценама појављивало више игром случаја. То је доба између осталог било осетно обележено мимолитерарним факторима, што је последица година фашистичке окупације и политичког разилаза наше државе с Југославијом у периоду 1948-1955. То је већ посебно поглавље наших узајамних културних веза.

${ }^{14}$ Видети Архив Института уметничке критике и позоришне документације у Братислави. 